\title{
Pengetahuan Pasien Tentang Diet Cairan dan Nutrisi pada Pasien Gagal Ginjal Kronik (GGK) Di Ruang Hemodialisa RSUD Kabupaten Indramayu Tahun 2017
}

\author{
Kitri Hikmawati ${ }^{1}$ \\ 1STIKes Indramayu, email: qeets2203@gmail.com
}

\section{ABSTRACT}

Chronic renal failure is a clinical condition of kidney damage which can cause the body fails to maintain metabolism and fluid and electrolyte balance, which causes uremia and fluid build up. Knowledge of diet fluids management and nutrition in renal failure patient is important to know and for those who are determined to reduce the risk of kidney disorders. The purpose of this research is to know the description of Patient's Knowledge about Fluid and Nutrition Diet in Chronical Renal Failure (GGK) in hemodialysis room of RSUD Indramayu 2017 ". This research uses descriptive method, the population in this study for about 127 and the sample in this study for about to 90 respondents in accordance with the inclusion criteria taken with Consecutive Sampling Technique. Data collection using questionnaire. Data were analyzed by Product Moment statistic test, with significance $a=0,05$. Based on the results of the study can be concluded that the knowledge of patients about diet fluids and nutrition for about 74 patients (82.2\%) respondents who have good knowledge. This research as an input for nurse hemodialisa room expected nurses can modify the delivery of health information through media and interesting methods about diet fluids and nutrition.

Keyword. Knowledge, Fluid and Nutrition Diet, CRF 


\section{ABSTRAK}

Gagal ginjal kronik merupakan keadaan klinis kerusakan ginjal dapat menyebabkan tubuh gagal untuk mempertahankan metabolisme serta keseimbangan cairan dan elektrolit sehingga mengakibatkan terjadinya uremia dan penumpukan cairan. Pengetahuan tentang penatalaksanaan diet cairan dan nutrisi pada penderita gagal ginjal penting untuk diketahui dan bagi mereka yang bertekad untuk menurunkan resiko terhadap gangguan ginjal. Tujuan penelitian ini untuk mengetahui gambaran Pengetahuan Pasien tentang Diet Cairan dan Nutrisi pada Pasien Gagal Ginjal Kronik (GGK) di ruang hemodialisa RSUD Indramayu tahun 2017". Metode penelitian ini menggunakan deskriptif, populasi dalam penelitian ini berjumlah 127 dan sampel dalam penelitian ini berjumlah 90 responden sesuai dengan kriteria inklusi yang diambil dengan teknik Consecutive Sampling. Pengumpulan data dengan menggunakan kuesioner. Analisa data menggunakan analisis univariat. Berdasarkan hasil penelitian dapat disimpulkan bahwa pengetahuan pasien tentang diet cairan dan nutrisi sebanyak $74 \quad(82,2 \%)$ responden yang memiliki pengetahuan dalam kategori baik. Peran perawat ruang hemodialisa diharapkan dapat memodifikasi penyampaian informasi kesehatan melalui media dan metode yang menarik mengenai diet cairan dan nutrisi.

Kata kunci. Pengetahuan, Diet Cairan dan Nutrisi, GGK 
Pendahuluan

Gagal ginjal kronik merupakan keadaan klinis kerusakan ginjal yang progresif dan irreversible dan dapat menyebabkan tubuh gagal untuk mempertahankan metabolisme serta keseimbangan cairan dan elektrolit sehingga mengakibatkan

terjadinya uremia dan penumpukan cairan, kemudian dapat mengancam

keselamatan hidup pada penderitanya (Smeltzer, S.C. \& Bare, B. G, 2008). Menurut estimasi WHO (2016), secara global lebih dari 500 juta orang dari sekitar 1,5 juta harus menjalani hemodialisa.

Berdasarkan data dari Riset Kesehatan Dasar (Riskesdas) tahun 2013 prevalensi gagal ginjal kronik di Indonesia sekitar 0,2 \% prevalensi kelompok umur $\geq 75$ tahun dengan $0,6 \%$ lebih tinggi dari kelompok umur lainnya.
Sementara itu di Jawa Barat tahun 2014 jumlah penderita gagal ginjal kronik sebanyak 3.654 orang (Indonesia Renal Registry, 2014). Hemodialisis

merupakan suatu metode terapi dialisis yang digunakan untuk mengeluarkan cairan dan produk limbah dari dalam tubuh ketika secara akut ataupun secara progresif ginjal tidak mampu melaksanakan proses tersebut. Terapi ini dilakukan dengan menggunakan sebuah mesin yang dilengkapi dengan membran penyaring semipermiabel (ginjal buatan) Muttaqin \& Sari (2011).

Diet untuk pasien hemodialisa dianjurkan untuk membatasi makanan yang mengandung kalium, air, dan garam (Marantika dan Devi, 2014). Buahbuahan dan sayursayuran biasanya mengandung kalium sehingga 
Kitri Hikmawati: Diet Cairan

disarankan untuk tidak mengkonsumsi hampir semua jenis buah serta makanan yang diolah dari buah. Membatasi konsumsi makanan yang mengandung garam dilakukan agar pasien tidak merasa haus. Rasa haus mendorong pasien untuk minum sehingga dapat menimbulkan kenaikan berat badan yang besar selama periode diantara dialysis Rahardjo et al., (2009).

Berdasarkan hasil studi pendahuluan yang dilakukan di ruang hemodialisa

RSUD

Kabupaten Indramayu pada tanggal 1-3 Maret 2017 bahwa didapatkan data pasien yang menjalani terapi hemodialisa sejumlah 143 orang. Berdasarkan hasil wawancara pada tanggal 21 April tahun 2017 didapatkan hasil dari 10 responden, 6 orang yang menjalani terapi hemodialisa selama 1 tahun dan 4 orang yang menjalani terapi hemodialisa selama 2 tahun. Dari 6 orang

diantaranya tersebut mengatakan 3 orang memakan buah seperti jeruk, jambu maupun pisang dan tidak terlalu memperdulikan jumlah air yang masuk, dimana dalam diet pada pasien GGK tidak dianjurkan untuk makan buah yang banyak mengandung kalium tersebut, dan 3 orang mengatakan masih mengonsumsi jeroan. Sedangkan dari 4 orang tersebut diantaranya 2 orang mengalami gejala sesak nafas, dan oedema ekstremitas, dan 2 orang lainnya mengatakan sudah tidak memakan jeroan, mampu menghindari buahbuahan dan sayursayuran yang tidak dianjurkan, serta mampu membatasi jumlah air yang masuk kedalam tubuh.

Berdasarkan uraian di latar belakang mendukung penulis melakukan penelitian tentang "Pengetahuan pasien tentang diet 
cairan dan nutrisi pada pasien gagal ginjal kronik (GGK) di ruang hemodialisa

RSUD

Kabupaten Indramayu tahun 2017".

\section{METODE PENELITIAN}

Teknik

pengambilan sampel pada penelitian ini menggunakan

Counsecutive sampling, yaitu semua pasien yang menjalani terapi hemodialisa di RSUD Kabupaten Indramayu yang terpilih berdasarkan kriteria inklusi yang sudah ditetapkan dengan jumlah 90 responden, sedangkan jumlah populasi yang didapatkan ada 127 responden.

Pengukuran pengetahuan yaitu menggunakan kuesioner, masingmasing sub variabel terdiri dari 9 pernyataan pengetahuan diet cairan dan 11 pernyataan pengetahuan diet nutrisi.

\section{HASIL \\ PEMBAHASAN}

Hasil penelitian tentang pengetahuan pasien tentang diet cairan dan nutrisi pada pasien gagal ginjal kronik (GGK) di Ruang Hemodialisa RSUD Kabupaten Indramayu, didapatkan bahwa umur tertua responden 58 tahun dan yang termuda adalah 18 tahun, mayoritas pasien gagal ginjal kronik berusia $\geq$ 40 tahun sebanyak 57 responden, berjenis kelamin laki-laki dan perempuan masingmasing sebanyak 45 responden,

berpendidikan terakhir sekolah dasar sebanyak 34 responden, mayoritas bekerja sebagai wiraswasta sebanyak 39 responden, yang menjalani hemodialisis yang paling lama 84 bulan dan yang paling baru adalah 2 bulan. Frekuensi hemodialisis paling sedikit yaitu 1 kali/minggu dan paling 
banyak yaitu 3 kali/minggu.

Penelitian ini membahas tentang pengetahuan diet cairan dan nutrisi secara umum, adapun secara khusus yaitu pengetahuan diet cairan dan pengetahuan diet nutrrisi, dan karakteristik berpengaruh yang diet cairan pengetahuan diet cairan berdasarkan menjalani hemodialisis dan umur, pengetahuan diet nutrisi berdasarkan lama menjalani hemodialisis dan umur disajikan dalam bentuk table sebagai berikut:

\section{Tabel 1}

Distribusi Frekuensi Berdasarkan Pengetahuan Diet Cairan dan Nutrisi di Ruang Hemodialisa RSUD

Kabupaten Indramayu Tahun 2017

\begin{tabular}{lcc}
\hline $\begin{array}{c}\text { Pengetahuan } \\
\text { diet cairan } \\
\text { dan nutrisi }\end{array}$ & $\begin{array}{c}\text { Frekuensi } \\
(\mathbf{F})\end{array}$ & $\begin{array}{c}\text { Persentase } \\
(\boldsymbol{\%})\end{array}$ \\
\hline Baik & 74 & 82,2 \\
Cukup & 10 & 11,1 \\
Kurang & 6 & 6,7 \\
\hline \multicolumn{1}{c}{ Total } & 90 & 100.0 \\
\hline
\end{tabular}

3 1 diatas diketahui bahwa sebanyak 74 $(82,2 \%)$ responden yang memiliki pengetahuan baik tentang diet cairan dan nutrisi.

Tabel 2

Distribusi Frekuensi Berdasarkan

Pengetahuan Diet Cairan di Ruang Hemodialisa RSUD Kabupaten Indramayu Tahun 2017

\begin{tabular}{lcc}
\hline $\begin{array}{c}\text { Pengetahuan } \\
\text { diet cairan }\end{array}$ & $\begin{array}{c}\text { Frekuensi } \\
(\mathbf{F})\end{array}$ & $\begin{array}{c}\text { Persentase } \\
(\boldsymbol{\%})\end{array}$ \\
\hline Baik & 73 & 81,1 \\
Cukup & 8 & 8,9 \\
Kurang & 9 & 10,0 \\
\hline \multicolumn{1}{c}{ Total } & 90 & 100.0 \\
\hline
\end{tabular}

Berdasarkan tabel 2 diketahui bahwa responden paling banyak yaitu sejumlah $73(81,1 \%)$ yang memiliki pengetahuan baik tentang diet cairan. 
Kitri Hikmawati: Diet Cairan

Tabel 3

Distribusi Frekuensi Berdasarkan

Pengetahuan

Nutrisi di

Hemodialisa

\begin{tabular}{|c|c|c|c|c|c|c|c|c|}
\hline \multirow{3}{*}{$\begin{array}{l}\text { Lama } \\
\text { HD }\end{array}$} & \multicolumn{6}{|c|}{ Pengetahuan diet cairan } & \multirow{2}{*}{\multicolumn{2}{|c|}{ Jumlah }} \\
\hline & \multicolumn{2}{|c|}{ Baik } & \multicolumn{2}{|c|}{ Cukup } & \multicolumn{2}{|c|}{ Kurang } & & \\
\hline & $\mathrm{n}$ & $\%$ & $\mathrm{n}$ & $\%$ & $\mathrm{n}$ & $\%$ & $\mathrm{n}$ & $\%$ \\
\hline$<1$ tahun & 23 & 67,6 & 4 & 11,8 & 7 & 20,6 & 34 & 100 \\
\hline $1-2$ tahun & 25 & 89,3 & 1 & 3,6 & 2 & 7,1 & 28 & 100 \\
\hline$\geq 2$ tahun & 25 & 89,3 & 3 & 10,7 & 0 & 0 & 28 & 100 \\
\hline Jumlah & 73 & 81,1 & 8 & 8,9 & 9 & 10 & 90 & 100 \\
\hline \multicolumn{9}{|l|}{ Umur } \\
\hline $\begin{array}{l}<20 \\
\text { tahun }\end{array}$ & 1 & 100 & 0 & 0 & 0 & 0 & 1 & 100 \\
\hline $\begin{array}{l}20-40 \\
\text { tahun }\end{array}$ & 27 & 84,4 & 2 & 6,3 & 3 & 9,4 & 32 & 100 \\
\hline $\begin{array}{l}\geq 40 \\
\text { tahun }\end{array}$ & 45 & 78,9 & 6 & 10,5 & 6 & 10,5 & 57 & 100 \\
\hline Jumlah & 73 & 81,1 & 8 & 8,9 & 9 & 10 & 90 & 100 \\
\hline
\end{tabular}

Berdasarkan table

Berdasarkan table 3 diketahui bahwa responden paling banyak yaitu sejumlah 67 $(74,4 \%)$ yang memiliki pengetahuan baik tentang diet nutrisi.

Tabel 4

Distribusi Frekuensi Pengetahuan Diet Cairan pada Pasien GGK Berdasarkan Lama

Hemodialisis dan Umur di Ruang Hemodialisa RSUD

Kabupaten

Indramayu

Tahun 2017
4 diketahui dari 28 responden menjalani hemodialisis $\geq 2$ tahun diketahui sebanyak 25 (89,3\%) responden dengan pengetahuan diet cairan dalam kategori baik. Diketahui dari 28 responden menjalani hemodialisis 1-2 tahun sebanyak 25 $(89,3 \%) \quad$ responden dengan pengetahuan diet cairan dalam kategori baik. Diketahui dari 34 responden menjalani hemodialisis < 1 tahun sebanyak 23 (67,6\%) responden dengan pengetahuan diet cairan dalam kategori baik. 


\section{Kitri Hikmawati: Diet Cairan}

Diketahui dari 57 responden umur $\geq 40$ tahun sebanyak 45 (78,9\%)

responden dengan pengetahuan diet cairan dalam kategori baik. Diketahui dari 32 responden umur 20-40 tahun diketahui sebanyak $27 \quad(84,4 \%)$ responden dengan pengetahuan diet cairan dalam kategori baik. Sebanyak 1 responden umur < 20 tahun sebanyak 1 (100\%) responden dengan pengetahuan diet cairan dalam kategori baik.
Tabel 5

Distribusi Frekuensi

Pengetahuan Diet Nutrisi pada Pasien GGK Berdasarkan Lama Hemodialisis dan Umur di Ruang Hemodialisa RSUD Kabupaten Indramayu Tahun 2017

\begin{tabular}{|c|c|c|c|c|c|c|c|c|}
\hline \multirow{3}{*}{$\begin{array}{c}\text { Lama } \\
\text { HD }\end{array}$} & \multicolumn{6}{|c|}{ Pengetahuan diet nutrisi } & \multirow{2}{*}{\multicolumn{2}{|c|}{ Jumlah }} \\
\hline & \multicolumn{2}{|c|}{ Baik } & \multicolumn{2}{|c|}{ Cukup } & \multicolumn{2}{|c|}{ Kurang } & & \\
\hline & $\mathrm{n}$ & $\%$ & $\mathrm{n}$ & $\%$ & $\mathrm{n}$ & $\%$ & $\mathrm{n}$ & $\%$ \\
\hline $\begin{array}{l}<1 \\
\text { tahun }\end{array}$ & 18 & 52,9 & 10 & 29,4 & 6 & 17,6 & 34 & 100 \\
\hline $\begin{array}{l}1-2 \\
\text { tahun }\end{array}$ & 22 & 78,6 & 5 & 17,9 & 1 & 3,6 & 28 & 100 \\
\hline $\begin{array}{l}\geq 2 \\
\text { tahun }\end{array}$ & 27 & 96,4 & 1 & 3,6 & 0 & 0 & 28 & 100 \\
\hline Jumlah & 67 & 74,4 & 16 & 17,8 & 7 & 7,8 & 90 & 100 \\
\hline \multicolumn{9}{|l|}{ Umur } \\
\hline $\begin{array}{l}<20 \\
\text { tahun }\end{array}$ & 1 & 100 & 0 & 0 & 0 & 0 & 1 & 100 \\
\hline $\begin{array}{l}20-40 \\
\text { tahun }\end{array}$ & 26 & 81,3 & 5 & 15,6 & 1 & 3,1 & 32 & 100 \\
\hline $\begin{array}{c}\geq 40 \\
\text { tahun }\end{array}$ & 40 & 70,2 & 11 & 19,3 & 6 & 10,5 & 57 & 100 \\
\hline Jumlah & 67 & 74,4 & 16 & 17,8 & 7 & 7,8 & 90 & 100 \\
\hline
\end{tabular}

Berdasarkan tabel 5 diketahui dari 28 responden menjalani hemodialisisis $\geq 2$ tahun sebanyak $27 \quad(96,4 \%)$ responden dengan pengetahuan diet nutrisi dalam kategori baik. Diketahui dari 28 responden menjalani hemodialisis 1-2 tahun 
sebanyak $22 \quad(78,6 \%)$ responden dengan pengetahuan diet nutrisi dalam kategori baik. Diketahui dari 34 responden menjalani hemodialisis < 1 tahun sebanyak $18 \quad(52,9 \%)$ responden dengan pengetahuan diet nutrisi dalam kategori baik.

Diketahui dari 57 responden umur $\geq 40$ tahun diketahui sebanyak $40 \quad(70,2 \%)$ responden dengan pengetahuan diet nutrisi dalam kategori baik. Diketahui dari 32 responden umur 20-40 tahun sebanyak 26 $(81,3 \%) \quad$ responden dengan pengetahuan diet nutrisi dalam kategori baik. Diketahui dari 1 responden umur < 20 tahun sebanyak 1 (100\%) responden dengan pengetahuan diet nutrisi dalam kategori baik.

\section{Pembahasan}

Pengetahuan

merupakan hasil tahu dan ini terjadi setelah seseorang melakukan pengindraan terhadap suatu objek tertentu (Notoatmodjo, 2010).

Hasil penelitian yang dilakukan pada 90 responden mengenai pengetahuan pasien diketahui bahwa pengetahuan pasien tentang diet cairan sebagian besar 73 $(81,1 \%) \quad$ responden memiliki pengetahuan baik. Hal ini dikarenakan

karakteristik responden yang ada di indramayu semakin mengerti dan memiliki pengetahuan yang baik bisa dilihat dari waktu/lamanya menjalani hemodialis diketahui dari 28 responden menjalani hemodialisis $\geq 2$ tahun diketahui sebanyak 25 $(89,3 \%) \quad$ responden dengan pengetahuan diet cairan dalam kategori baik. Sebanyak 28 responden menjalani hemodialisis 1-2 tahun sebanyak $25 \quad(89,3 \%)$ responden dengan pengetahuan diet cairan dalam kategori baik. Sebanyak 34 responden 
menjalani hemodialisis < 1 tahun sebanyak 23 (67,6\%) responden dengan pengetahuan diet cairan dalam kategori baik. Hal tersebut dikarenakan semakin lama menjalani hemodialisa, semakin banyak mendapatkan edukasi dari perawat. Hal diatas menunjukkan hasil penelitian ini sebagian besar responden mengerti tentang aturan diet cairan yang mana seperti dalam melakukan pembatasan cairan dapat mengontrol kenaikan berat badan, mengurangi sesak nafas dan bengkak, responden juga mampu menghitung cairan yang boleh diminum yaitu sebanyak jumlah urin ditambah dengan $\pm 1 / 2$ liter, maupun tentang pemantauan berat badan sebagai acuan diet cairan, juga pasien mengaku patuh terhadap aturan diet cairan tersebut. Mayoritas responden yang bekerja sebagai wiraswasta sebanyak 39 responden dari berbagai bidang, sehingga seseorang yang memiliki pekerjaan akan memperoleh informasi dari berbagai pihak, khususnya tentang pengetahuan gagal ginjal kronik dan pantangan yang harus dipatuhi. Tingkat kematangan dan berpikir seseorang juga bisa dipengaruhi oleh pengalaman dan informasi-informasi dalam kehidupan seharihari, dan sesuai dengan pengalaman ketika pasien mematuhi peraturan seperti mengonsumsi cairan sesuai dengan kebutuhan, maka kondisi pasien pun akan baik, berbeda jika pasien telah melanggar aturan yang ada, maka timbulah tanda dan gejala yang tidak kita inginkan seperti kondisi pasien yang akan semakin memburuk.

\begin{tabular}{lcr} 
Usia & responden \\
diketahui & dari & 57 \\
responden & umur $\geq$ & 40 \\
tahun & \multicolumn{2}{c}{ (Dewasa }
\end{tabular}


menengah) sebanyak 45 (78,9\%)

responden dengan pengetahuan diet cairan dalam kategori baik. Sebanyak 32 responden umur 2040 tahun (Dewasa muda) diketahui sebanyak 27 $(84,4 \%)$ responden dengan pengetahuan diet cairan dalam kategori baik. Sebanyak 1 responden umur $<20$ tahun (Remaja) sebanyak $1 \quad(100 \%)$ responden dengan pengetahuan diet cairan dalam kategori baik, usia sangat berpengaruh terhadap pengetahuan seseorang, karena pada usia yang sangat dewasa akan semakin banyak pengetahuan yang dimiliki dan memiliki motivasi kuat keinginannya untuk sembuh agar penyakit mereka tidak berlanjut ke stadium yang lebih tinggi.

Faktor yang dapat mempengaruhi

pengetahuan seseorang menurut Sumilati \& Soleha (2014) tentang hubungan tingkat pengetahuan dengan kepatuhan diet pada pasien gagal ginjal kronik yang dilakukan hemodialisis regular di Rumah Sakit Darmo Surabaya yaitu terdapat usia, pendidikan, pekerjaan. Usia responden sebagian berusia 50 tahun. Usia sangat berpengaruh terhadap pengetahuan seseorang karena usia yang sangat dewasa akan semakin banyak pengetahuan

dimiliki. yang setengah

Hampir responden pekerja swasta dari berbagai bidang, sehingga seseorang yang memiliki pekerjaan akan memperoleh informasi dari berbagai pihak. Hampir setengahnya responden berpendidikan menengah. Pengetahuan tidak hanya diperoleh dari pendidikan saja, akan tetapi pengalaman juga berperan penting terhadap pengetahuan yang diperoleh seseorang. 
Nursalam (2001) dalam Sumilati \& Soleha (2014) berpendapat bahwa umumnya seseorang yang bekerja cenderung mempunyai pengetahuan yang cukup baik daripada yang tidak bekerja. Hal ini disebabkan karena orang dilingkungan kerja merupakan sumber informasi yang dapat menambah pengetahuan seseorang selain media elektronik.). Tidak dapat dipungkiri bahwa jika seseorang tingkat pendidikannya tinggi maka semakin mudah pula pengetahuan yang dimiliki. Walaupun pendidikan tidak tinggi akan tetapi mempunyai pengalaman yang banyak akan mempengaruhi pengetahuan itu sendiri. Menurut Nursalam (2003) dalam Sumilati \& Soleha (2014) berpendapat bahwa semakin bertambah usia seseorang maka pengetahuan bertambah mereka pengetahuan karena bukan hanya berasal dari lingkungan maupun tingkat pendidikan tetapi pengalaman mereka dalam menghadapi realita kehidupan.

Beberapa faktor yang menyebabkan pengetahuan responden baik menurut Anita (2004) dalam Nastiti (2015) antara lain adanya konseling kesehatan serta lama menjalani hemodialisa, maka seseorang akan bertambah wawasan pengetahuan yang luas terkait hemodialisa. Pengetahuan yang lebih luas memungkinkan pasien itu dapat mengontrol dirinya dalam mengatasi masalah yang dihadapi, lebih mempunyai rasa percaya tinggi, berpengalaman, dan mempunyai perkiraan yang tepat bagaimana mengatasi kejadian serta mudah mengerti tentang apa yang dianjurkan oleh petugas kesehatan, juga akan mengurangi kecemasan sehingga dapat membantu 
individu tersebut dalam membuat keputusan.

$$
\text { Asupan cairan }
$$

penyakit gagal ginjal kronik harus

disesuaikan dengan batas asupan cairan yang sudah ditentukan, rasa haus yang dialami pasien menyebabkan terjadinya fenomena kelebihan cairan pada klien yang menjalani terapi hemodialisis. Berat badan harian merupakan parameter penting yang dipantau, selain catatan yang akurat mengenai asupan dan keluaran. Rasa haus akan muncul ketika osmolalitas plasma 295 $\mathrm{mOsm} /$. Asupan cairan pada individu dewasa berkisar 15003500ml/hari, sedangkan haluaran cairannya adalah $2300 \mathrm{ml} /$ hari. Cairan dapat keluar dari beberapa organ tubuh, yaitu : kulit, paru-paru, pencernaan, ginjal kg (Mubarak \& Chayatin, 2008).

Hasil penelitian yang dilakukan pada 90 responden mengenai pengetahuan

diketahui

pasien

pengetahuan

tentang diet nutrisi sebagian besar

67

$(74,4 \%) \quad$ responden memiliki pengetahuan baik. Pengetahuan yang baik dilihat dari penelitian ini hampir seluruhnya responden mengetahui tentang makanan yang boleh dimakan antara lain telur, daging, ikan dan ayam, pasien mengetahui bahwa jeroan (hati, usus, limpa) adalah makanan yang perlu dihindari, bagitu juga tempe dan tahu harus dibatasi, lalu untuk mengonsumsi buah dengan cara dipotong-potong lalu dicuci dan direndam dengan air hangat.

$\mathrm{Hal}$ diatas menunjukkan karena karakteristik responden yang ada di indramayu semakin mengerti dan memiliki pengetahuan yang baik bisa dilihat dari waktu/lamanya menjalani hemodialisis diketahui dari 28 
responden menjalani hemodialisisis $\geq 2$ tahun sebanyak $27 \quad(96,4 \%)$ responden dengan pengetahuan diet nutrisi dalam kategori baik. Diketahui dari 28 responden menjalani hemodialisis 1-2 tahun sebanyak $22 \quad(78,6 \%)$ responden dengan pengetahuan diet nutrisi dalam kategori baik. Diketahui dari 34 responden menjalani hemodialisis < 1 tahun sebanyak $18 \quad(52,9 \%)$ responden dengan pengetahuan diet nutrisi dalam kategori baik, dilihat dari lamanya menjalani terapi hemodialisis mempunyai pengaruh terhadap pengetahuan karena semakin lamanya pasien menjalani terapi hemodialisis semakin menambah informasi dari tenaga medis maupun dari pasien lain. Tingkat

kematangan dan berpikir seseorang dipengaruhi pengalaman juga informasi-informasi dalam kehidupan seharihari dan sesuai dengan pengalaman ketika pasien mematuhi peraturan seperti mengonsumsi makanan sesuai dengan yang dianjurkan, maka kondisi pasien pun akan baik, berbeda jika pasien telah melanggar aturan yang ada, maka timbulah tanda dan gejala yang tidak kita inginkan seperti kondisi pasien yang akan semakin memburuk contohnya sesak ketika memakan sayur dan buah yang banyak mengandung tinggi kalium, memakan jeroan seperti hati, ampela, usus yang mengandung tinggi purin yang akan semakin memperburuk kondisi pasien.

Berdasarkan usia diketahui dari 57 responden umur $\geq 40$ tahun diketahui sebanyak $40 \quad(70,2 \%)$ responden dengan pengetahuan diet nutrisi dalam kategori baik. Diketahui dari 32 responden umur 20-40 
tahun sebanyak 26 $(81,3 \%) \quad$ responden dengan pengetahuan diet nutrisi dalam kategori baik. Diketahui dari 1 responden umur < 20 tahun sebanyak 1 (100\%) responden dengan pengetahuan diet nutrisi dalam kategori baik. Hal ini karena usia sangat berpengaruh terhadap pengetahuan seseorang, karena pada usia yang sangat dewasa akan semakin banyak pengetahuan yang dimiliki dan memiliki motivasi kuat keinginannya untuk sembuh agar penyakit mereka tidak berlanjut ke stadium yang lebih tinggi.

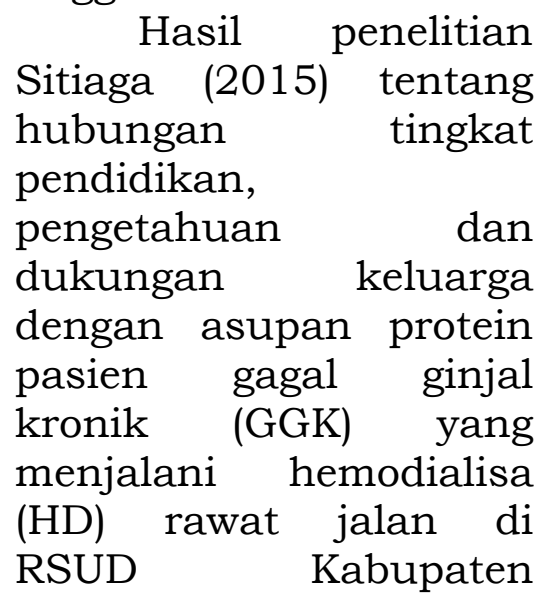

Sukoharjo menunjukan bahwa dari 31 responden diketahui sebagian besar responden memiliki pengetahuan baik dengan asupan protein sebesar $(58,06 \%)$ hal tersebut sehingga pasien dapat mencegah terjadinya komplikasi yang disebabkan oleh asupan yang dikonsumsi. Hasil penelitian lain yang dilakukan oleh Nastiti (2015) tentang hubungan tingkat pendidikan dan pengetahuan gizi terhadap asupan kalium pada pasien gagal ginjal kronik yang menjalani hemodialisa rawat jalan di RSUD Sukoharjo mengungkapkan bahwa sebagian besar pengetahuan responden dengan asupan kalium dalam kategori baik sebesar (42\%), hal ini dikarenakan semakin tinggi pendidikan dan pengetahuan gizi maka semakin rendah asupan kalium yang dikonsumsi. 
Kitri Hikmawati: Diet Cairan

Tujuan terapi diet dan intervensi nutrisi pada pasien yang dilakukan hemodialisis antara lain : untuk mencapai dan menjaga status nutrisi yang baik, untuk mencegah atau memperlambat penyakit kardiovaskuler, cerebrovaskuler dan penyakit vaskuler perifer, untuk mencegah atau menangani hiperparatiroidisme dan bentuk-bentuk lain dari osteodystrophy ginjal dan untuk mencegah atau memperbaiki keracunan uremik dan gangguan metabolik lain, yang dipengaruhi nutrisi, yang terjadi pada gagal ginjal dan tidak dapat teratasi secara adekuat dengan hemodialisis. Agar tujuan dan keinginan tercapai, sangat penting untuk dilakukan pendidikan kesehatan tentang prinsip-prinsip terapi diet dan targetnya (Cahyaningsih, 2011).

\section{SIMPULAN}

Berdasarkan hasil penelitian tentang pengetahuan pasien tentang diet cairan dan nutrisi pada pasien gagal ginjal kronik (GGK) di ruang hemodialisa RSUD Kabupaten Indramayu tahun 2017, dapat disimpulkan sebagai berikut :

\section{Gambaran}

pengetahuan pasien tentang diet cairan dan nutrisi pada pasien gagal ginjal kronik (GGK) di ruang hemodialisa RSUD

Kabupaten Indramayu tahun 2017 sebanyak 74 (82,2\%) responden yang memiliki pengetahuan baik.

2. Gambaran

pengetahuan pasien tentang diet cairan pada pasien gagal ginjal kronik (GGK) di ruang hemodialisa RSUD Kabupaten Indramayu tahun 2017 sebanyak 73 $(81,1 \%)$ yang memiliki pengetahuan baik. 
Kitri Hikmawati: Diet Cairan

3. Gambaran

pengetahuan

pasien

tentang diet nutrisi pada pasien gagal ginjal kronik (GGK) di ruang hemodialisa RSUD Kabupaten Indramayu tahun 2017 sebanyak 67 (74,4\%) yang memiliki pengetahuan baik.

\section{SARAN}

Berdasarkan hasil penelitian dan kesimpulan yang telah diperoleh, maka diajukan saran-saran sebagai berikut :

1. Bagi

Institusi

Pelayanan Kesehatan, diharapkan perawat dapat memodifikasi penyampaian informasi kesehatan melalui media dan metode yang menarik mengenai pembatasan asupan cairan dan nutrisi.

2. Bagi institusi pendidikan, Saran untuk institusi pendidikan yang akan mencetak tenaga perawat, diharapkan

memasukan teori

pengetahuan dan konsep diet pada pasien gagal ginjal kronik lebih di pertegaskan untuk meningkatkan kompetensi dalam hal komunikasi terapeutik terkait pengetahuan diet pada pasien gagal ginjal kronik.

3. Bagi tempat penelitian, Sebagai bahan masukan dalam meningkatkan mutu pelayanan terhadap pasien gagal ginjal kronik.

4. Bagi peneliti, untuk menambah wawasan dan pengetahuan peneliti tentang Pengetahuan Pasien tentang Diet Cairan dan Nutrisi pada pasien Gagal Ginjal Kronik (GGK) di Ruang Hemodialisa 
Kitri Hikmawati: Diet Cairan

RSUD Kabupaten

Indramayu.

5. Bagi

penelitian

selanjutnya, hasil penelitian ini dapat digunakan sebagai data dalam mengembangkan penelitian selanjutnya yaitu faktor-faktor yang mempengaruhi pengetahuan diet cairan dan nutrisi.

\section{DAFTAR PUSTAKA}

Smeltzer, S. C. \& Bare, B. G. 2008. Brunner and Suddarth's

Texbook Of Medical Surgical Nursing. Lippincott; Philadelphia.

World

Health

Organization

(WHO). 2016.

Gagal Ginjal Kronik. (Diakses pada Tanggal 16 Desember 2016 Pukul 11.00 WIB).

Riset Kesehatan Dasar. 2013. Laporan
Nasional

Riskesdas 2013.

Dari

http://litbang.dep kes.go.id. (Diakses pada Tanggal 10 Februari 2017 Pukul 17.00 WIB). Indonesia Renal Registry (IRR). 2014. $\quad 7^{\text {th }}$ Report Of Indonesia Renal Registry 2011. (Diakses pada Tanggal 15 Desember 2016. Pukul 14.00 WIB). Muttaqin, A. \& Sari, K. 2011. Asuhan Keperawatan

Gangguan Sistem Perkemihan.

Jakarta : Salemba Medika.

Marantika, Devi, P, N. 2014. Gambaran Kepatuhan

Terhadap Anjuran Medis pada Pasien Gagal Ginjal Terminal yang Menjalani Terapi Hemodialisa di Kota Medan. Universitas Sumatera Utara. (Diakses pada 
Tanggal 8 Juni 2017 Pukul 16.00 WIB).

Rahardjo, J. P., Susalit, E., \& Suhardjono. 2009.

Dalam Sodoyo, Aru W., Setiyohadi, B., Alwi, I., $\mathrm{K}$, Simardibrata M., \& Setiadi, S (Eds.). 2006. Buku Ajar Ilmu Penyakit Dalam Jilid II Edisi V. Jakarta: Interna Publishing.

Notoatmodjo. 2010. Metode Penelitian Kesehatan.

Jakarta : Rineka Cipta.

Sumilati \& Soleha. 2014. Hubungan Tingkat Pengetahuan dengan Kepatuhan Diet pada Pasien Gagal Ginjal Kronik yang dilakukan Hemodialisis

Regular di Rumah Sakit Darmo

Surabaya.

Nastiti. 2015. Hubungan

Tingkat Pendidikan dan Pengetahuan Gizi Terhadap Asupan Kalium pada Pasien Gagal

Ginjal Kronik yang Menjalani

Hemodialisa Rawat Jalan di RSUD Sukoharjo.

Mubarak, W. I \& Chayatin, N. 2008. Buku Ajar Kebutuhan Dasar Manusia: Teori dan Aplikasi

Dalam Praktik. Jakarta: EGC.

Sitiaga. 2015. Hubungan

Tingkat

Pendidikan,

Pengetahuan, dan

Dukungan

Keluarga dengan

Asupan Protein

Pasien Gagal

Ginjal Kronik

(GGK) yang

Menjalani

Hemodialisa (HD)

Rawat Jalan di

RSUD Kabupaten

Sukoharjo.

Cahyaningsih, D Niken.

2011. Panduan

Praktis Perawatan

Gagal Ginjal.

Mitra. Yogyakarta:

Cendekia Press

Kusnul, Z., \& Munir, Z. (2012).

Efek 
Kitri Hikmawati: Diet Cairan

pemberian jus

mentimun terhadap

penurunan tekanan

darah. PROSIDING

Seminar Nasional, 1(2).

Munir, Z. (2019).

EFFECT OF

LOWERING THE

WATERMELON

JUICE BLOOD

PRESSURE ON

HYPERTENSION.

Jurnal Ilmiah STIKES

Citra Delima Bangka

Belitung, 3(2), 10-14. 